\title{
Selected aspects of risk management in Polish and Slovak SMEs
}

\author{
Katarína Havierniková1, Malgorzata Okreglicka ${ }^{2}$, Marcel Kordoš ${ }^{1}$ \\ ${ }^{1}$ Faculty of Social and Economic Relation, Alexander Dubček University of Trenčín \\ 2 Faculty of Management, Czestochowa University of Technology
}

\begin{abstract}
The principles of risk management come to the forefront of managers of both large and small enterprises. The trend in risk management consists of a comprehensive approach to risk management that penetrates within all key processes in the enterprise. Although the small and medium sized enterprises (SMEs) become to the important pillars of each economy, the risk management in these entities is elaborated only partially. This is affected mainly by attitudes of SMEs' owners or managers to risks, the lack of knowledge and practical experience in applying risk management. This paper contributes to the wide spreading of knowledge in the area of risk management in SMEs. The main aim of the paper is to compare the selected aspects of risk management between Polish and Slovak SMEs. The compared aspects are: authority to risk management in SMEs, ways of risk identification and risk assessment as well as risk limiting. The research is based on the results of questionnaire survey realized among 150 of Polish and 123 of Slovak SMEs. For the evaluation, the Chi-square test was used.
\end{abstract}

Keywords: small and medium sized enterprise, risk, risk management, organization, responsibility, ways of risk identification.

\section{Introduction}

Today, the SMEs are influenced by a number of factors that may fundamentally undermine their business and financial result. The ongoing processes in SMEs are realized under the influence of factors from internal and external business environment. These factors are the source of risks, threats and crises that should be avoided, or their effects should be limited or excluded (Hudáková et al., 2013). SMEs are very sensitive to 
changes in the entrepreneurial environment, which after some time are always reflected in the quantitative characteristics of this sector. Today, managers are increasingly faced with the responsibility to take important decisions to ensure prosperity and financial stability under the conditions of uncertainty and risk. More and more businesses, not just large but also small ones, are beginning to realize the need and importance of risk management. New trends in risk management bring idea that it is necessary to pay permanent attention to assess key business risks in business external environment.

Small and medium-sized enterprises represent an important part of the economies in developed countries and the same situation is in Slovakia and Poland. Small and medium-sized entrepreneurs have particularly good conditions for risk management as they are in close proximity to all aspects of individual operations, and they recognize many strengths and vulnerabilities in their businesses.

The knowledge of the key risks and implementation of the risk management in the companies is also an opportunity to increase the performance efficiency or to achieve costs savings. Investments in prevention will bring savings of the financial costs compared with the expenses for solving the subsequences of the negative events. Therefore, it is necessary to improve the awareness and to inform the managers about managing risks in the enterprises worldwide, and in Slovakia as well as Poland. It is important for company managers to be able to identify the most serious risks, to create a space for discussions and to implement the whole risk management system in the companies with an emphasis on preventing the company crises (Hudáková and Masár, 2018). There are currently many companies that must deal with this issue. They obtain useful information and also use the appropriate tools in order to avoid bankruptcy (Weissová, Siekelova and Kramárová, 2017).

The essence of this paper is to compare selected aspects of risk management defined by the SME owners and managers in Slovakia and Poland. The paper is based on the empirical research and using of statistical methods.

\section{Literature review}

Small and medium-sized enterprises (SMEs) play an important role in most economies worldwide. For instance, in the European Union, around 99\% of the economic activities can be traced back to SMEs, which account for two thirds of all jobs in the private sector. Compared to larger firms, SMEs are usually seen as having simpler internal organization and thus as being more flexible and faster at responding and adapting to change (Caha, 2017). At the same time, SMEs are frequently confronted with major challenges. Compared to larger enterprises, SMEs profit less often from economies of scale and fewer have access to a wide resource base. Due to the usually low equity ratio of SMEs, they are relatively vulnerable to external events compared to larger enterprises. This illustrates that not only larger enterprises face various risks, but also SMEs, whose survival is more easily threatened due to their smaller set of - both financial and nonfinancial - resources (Hanulakova and Dano, 2018). 
According to Mura and Kljucnikov (2018), risk management process may help SMEs managers to identify significant risks that could jeopardize the success or existence of the company in time to efficiently cope with them. Misjudging or failing to recognize risks can - in the worst case - have disastrous consequences, ranging from customer loss to damaging liability, environmental damage and possibly even bankruptcy. However, many SMEs do not - or not adequately - apply risk management practices, mostly because they cannot afford to rededicate resources due to their constraints (Krajnakova, Navikaite and Navickas, 2015).

According to Lipkova and Braga (2016) over the last ten years, however, corporate risk management (CRM) has expanded well beyond insurance and the hedging of financial exposures to include a variety of other kinds of risk - notably operational risk, reputational risk, and, most recently, strategic risk. In addition, at a large and growing number of companies, the risk management function is directed by a senior executive with the title of chief risk officer (CRO) and overseen by a board of directors charged with monitoring risk measures and setting limits for these measures. Abrhám and Lžičař (2018) argue that a corporation can manage risks in one of two fundamentally different ways: one risk at a time, on a largely compartmentalized and decentralized basis; or all risks viewed together within a coordinated and strategic framework. Jenicek (2016) states that companies that succeed in creating an effective corporate risk management have a long-run competitive advantage over those that manage and monitor risks individually

By reducing risk, a company can reduce the amount of expensive equity capital needed to support its operating risks. In this sense, risk management can be viewed as a substitute for equity capital, and an important part of the job of the CRO and top management is to evaluate the tradeoff between more active risk management and holding a larger buffer stock of cash and equity. For companies without a large buffer of excess equity, a sharp drop in cash flow and value can lead to financial distress and a further (permanent) loss of value from underinvestment (Nocco and Stulz, 2016). What management can accomplish through an CRM program, then, is not to minimize or eliminate, but rather to limit, the probability of distress to a level that management and the board agrees is likely to maximize firm value (Lipkova and Hovorkova, 2018). Minimizing the probability of distress, which could be achieved by investing most of the firm's capital in Treasury bills, is clearly not in the interests of shareholders. Management's job is rather to optimize the firm's risk portfolio by trading off the probability of large shortfalls and the associated costs with the expected gains from taking or retaining risks (Boukalova, Kolarova and Lostak, 2016).

Hudáková and Dvorský (2018) highlight the positive influences of the risk management on making decisions in the environment of the risks, on the quality of the information provided, on increasing the company value, on ensuring its competitiveness, on achieving constant improvements and on the prevention in the framework of ensuring a continuous operation of the enterprise. Significant global investors have a similar opinion, and say they have no aversion against the risk, but they feel aversion towards 
surprises and, therefore, require a larger transparency of the companies concerning the risk management. According to Helisek (2015) the companies worldwide attempt to implement the risk management to the planning and decision-making process, i.e. they systematically consider the possible risks when making decisions. They link the risk strategy with the company strategic planning and inform the top management about the most serious risks.

Muller (2006) argues that the risk is qualitative and quantitative expression of threat, the level and degree of threat, and probability of its occurrence as a specified phenomenon and its consequences. The risk arises as an uncertainty in the fulfilment of objectives. Nowadays, risk management becomes an integral part of strategic management. Risk Management Department has given priority at the top level of corporate risk management. Risk managers identify the risks, opportunities, analyze, evaluate risks and control the course of its management (Lipkova, Gress and Poncarova, 2017).

Risk management may help SMEs managers to identify significant risks. Haviernikova, Okreglicka and Klučka (2016) state that risk management is one of the tools that enable increase of security by various processes and specific activities. Risk management represents large complex of problems for businesses. An important role is played by prevention which reduces the consequences of wrong decisions and represents a planned and targeted action, set by rules that aim to minimize the possibility of erroneous decision. To achieve effective risk management, the authors such as Caha (2018); Jiroudkova and Rovna (2015); Machkova and Sato (2017); Sejkora (2014) describe the basic conditions as precisely defined strategy of business entity against its main objectives, including risk strategy, further functioning comprehensive process of risk management supported by appropriate information system, a sufficient emphasis on risk management and those responsible for risk management. An important condition is also functioning of internal corporate culture and ability to advance and adapt to new risk challenges. The risk management according to Sira, Kravcakova Vozarova and Radvanska (2016) involves:

- identification of risk, risk processes and factors (see also Taušer and Čajka, 2014);

- ensuring staff resources;

- use of communication on purposes and the results of the measures implemented (see also in Ivanová and Masárová, 2018);

- constant search for opportunities and improvement of processes (see also in Zadrazilova, 2016);

- focus on the real causes of process failures;

- providing information to interested parties about the risk;

- planning of preventive and corrective measures;

- focusing of prevention on the reliability of the human factor;

- focus on prevention of systemic changes; 
- reduce the incidence and consequences of failures, misfits, reducing quality defects etc. (see also in Jirankova and Hnat, 2012);

- continuous and comprehensive evaluation of the effectiveness of risk prevention in terms of the effectiveness of corrective and preventive measures - their overall impact;

- application of the principles of project management and change management.

\section{Methods and Data}

The questionnaire surveys were realized within the project VEGA No 1/0918/16 Risk management of SMEs in the context of clusters' involvement activities in the Slovak Republic. The representative sample was addressed in accordance with the conditions defined in the literature. According to Borrego et al., (2009) and Caha and Šulistová (2016) the aim of qualitative research that is targeting on smaller groups is to examine in detail the specific context. The aim is not to provide a broad, generalizable description that is representative of most situations, but rather to describe a particular situation in sufficient depth to make the full meaning of what is happening clear. The structure of research sample presents table 1 .

Tab. 1: The structure of respondents

\begin{tabular}{|l|c|c|c|}
\hline Number of employees & Poland & Slovakia & Total \\
\hline Less than 10 & 74 & 84 & 158 \\
\hline $10-49$ & 58 & 27 & 85 \\
\hline $50-249$ & 18 & 12 & 30 \\
\hline Total & $\mathbf{1 5 0}$ & $\mathbf{1 2 3}$ & $\mathbf{2 7 3}$ \\
\hline
\end{tabular}

Source: Own research.

The most SMEs belonged to category of microenterprises (less than 10 employees), 49.33\% in case of Poland and 38.76\% in Slovakia.

For this research, four working hypotheses were stated. First two hypotheses contain null hypothesis ( $\mathrm{HO}$ ) and alternative hypothesis (HA), which were evaluated by Pearson chi-square test:

H1: H0 - There is no statistically significant dependence between the Polish and Slovak entities directly authorized to risk management in SMEs. HA - There is statistically significant dependence between the Polish and Slovak entities directly authorized to risk management in SMEs.

$\mathrm{H} 2$ : H0 - There is no statistically significant dependence between the Polish and Slovak SMEs' ways of risk identification. HA - There is statistically significant dependence between the Polish and Slovak SMEs' ways of risk identification.

H3: The methods used for risk identification and assessment differ in Polish and Slovak SMEs.

H4: The ways of risk limiting differ in Polish and Slovak SMEs. 
For the evaluation of respondents' answers, we used basic descriptive statistics and mathematical and statistical methods (Pearson Chi-square test). The hypotheses are evaluated on confidence level 0.05 according results of $p$-value. If the calculated $p$-value is lower than the test level ( $p<0.05$ ), we reject the null hypothesis (H0) and accept the alternative (HA).

\section{Results and Discussion}

The responsibility for risk management in SMEs is naturally associated with the owner of enterprise or top management. This statement confirmed also the results of our research between Polish and Slovak SMEs. In Poland, in $86.67 \%$ of cases, the responsibility for risk management lies on owners, in Slovakia it is in $81.30 \%$ of cases.

Tab. 2: Authorization to risk management within SMEs

\begin{tabular}{|l|c|c|c|}
\hline Responsible person & Poland & Slovakia & Total \\
\hline owner & 130 & 100 & $\mathbf{2 3 0}$ \\
\hline risk manager & 3 & 11 & $\mathbf{1 1}$ \\
\hline board members & 8 & 3 & $\mathbf{4}$ \\
\hline $\begin{array}{l}\text { supervisory board } \\
\text { members }\end{array}$ & 1 & 3 & $\mathbf{6}$ \\
\hline external staff & 1 & 1 & $\mathbf{5}$ \\
\hline nobody & 5 & 0 & $\mathbf{2 7 3}$ \\
\hline others & 2 & $\mathbf{1 2 3}$ & \\
\hline Total & $\mathbf{1 5 0}$ & $\mathbf{2}$ & \\
\hline \multicolumn{2}{|c|}{ Chi-Sq. $=\mathbf{1 7 , 2 5 6 ;} \mathbf{p = 0 , 1 8 8}$} \\
\hline
\end{tabular}

Source: Own research.

The results of $\mathrm{p}$-value of Chi-square test for $\mathrm{H} 1$ showed that we accept the null hypothesis. It means that there is no statistically significant dependence in entities authorized to risk management within SMEs, if the respondent comes from Poland or Slovakia.

If we compared the sized category of respondents in both countries, we can observe differences among their responses. The results showed table 3. Due to the results of Chisquare statistic in Poland as well as in Slovakia (the calculated p-values are less than 0.05), we can conclude that in this case, there is an association between enterprise size described by number of employees and categories of respondents due to the authorization to risk management in SMEs.

Tab. 3: Authorization to risk management within SMEs versus enterprise size by number of employees (\%)

\begin{tabular}{|l|c|c|c|c|c|c|c|c|}
\hline \multirow{2}{*}{ Responsible person } & \multicolumn{4}{|c|}{ Poland } & \multicolumn{4}{c|}{ Slovakia } \\
\cline { 2 - 10 } & ME & SE & MDE & Total & ME & SE & MDE & Total \\
\hline owner & 46.00 & 32.00 & 8.67 & $\mathbf{8 6 . 6 7}$ & 63.41 & 13.82 & 4.07 & $\mathbf{8 1 . 3 0}$ \\
\hline risk manager & 0.00 & 1.33 & 0.67 & $\mathbf{2 . 0 0}$ & 2.44 & 3.25 & 3.25 & $\mathbf{8 . 9 4}$ \\
\hline board members & 0.67 & 3.33 & 1.33 & $\mathbf{5 . 3 3}$ & 0.00 & 1.63 & 0.81 & $\mathbf{2 . 4 4}$ \\
\hline $\begin{array}{l}\text { supervisory board } \\
\text { members }\end{array}$ & 0.00 & 0.67 & 0.00 & $\mathbf{0 . 6 7}$ & 0.81 & 0.81 & 0.81 & $\mathbf{2 . 4 4}$ \\
\hline
\end{tabular}




\begin{tabular}{|l|c|c|c|c|c|c|c|c|}
\hline external staff & 0.00 & 0.00 & 0.67 & $\mathbf{0 . 6 7}$ & 1.63 & 1.63 & 0.81 & $\mathbf{4 . 0 7}$ \\
\hline nobody & 2.67 & 0.67 & 0.00 & $\mathbf{3 . 3 3}$ & 0.00 & 0.00 & 0.00 & $\mathbf{0 . 0 0}$ \\
\hline others & 0.00 & 0.67 & 0.67 & $\mathbf{1 . 3 3}$ & 0.00 & 0.81 & 0.00 & $\mathbf{0 . 8 1}$ \\
\hline Total & $\mathbf{4 9 . 3 3}$ & $\mathbf{3 8 . 6 7}$ & $\mathbf{1 2 . 0 0}$ & $\mathbf{1 0 0}$ & $\mathbf{6 8 . 2 9}$ & $\mathbf{2 1 . 9 5}$ & $\mathbf{9 . 7 6}$ & $\mathbf{1 0 0}$ \\
\hline \multicolumn{7}{|l}{} \\
\hline
\end{tabular}

Source: Own research.

Important part of risk management is the way, how the risks are identified. The respondents were allowed to select one of the following possibilities:

1. we do not deal with any risk,

2. risks are identified only by person responsible for risk management who is dealing with a risk,

3. risks are identified by an internal audit,

4. risks are identified by responsible person in co-operation with other employees who is dealing with a risk,

5. risks are identified in other way.

Table 4 presents the results of respondents' answers toward hypothesis H2. In the most Polish SMEs $(40.00 \%)$, the risks are identified only by person responsible for risk management who is dealing with a risk. In Slovakia, in $40.65 \%$ of cases, for the risk identification is responsible person, who co-operates with other employees who is dealing with risk. Due to the results of tested statistic Chi-square, the answers about risk identification ways are dependent on countries from which SME comes.

Tab. 4 The ways of risk identification in Poland and Slovakia

\begin{tabular}{|l|c|c|c|}
\hline Possibility & Poland & Slovakia & Total \\
\hline 1. & 48 & 18 & $\mathbf{6 6}$ \\
\hline 2. & 60 & 28 & $\mathbf{8 8}$ \\
\hline 3. & 7 & 19 & $\mathbf{2 6}$ \\
\hline 4. & 29 & 50 & $\mathbf{7 9}$ \\
\hline 5. & 6 & 8 & $\mathbf{2 7 3}$ \\
\hline Total & $\mathbf{1 5 0}$ & $\mathbf{1 2 3}$ \\
\hline \multicolumn{2}{|r|}{ Chi-Sq.= 34.345; df =9; $\mathbf{p = 0 . 0 0 0}$} \\
\hline
\end{tabular}

Source: Own research.

The comparison of the SMEs' answers according their sized category about the risk identification presents table 5. Accordingly, 18.67\% of micro enterprises in Poland don't deal with any risk and in the same amount of entities risks are identified only by person responsible for risk management who is dealing with a risk. In Slovakia, in this category, the most respondents (26.83\%), the risks are identified by responsible person in cooperation with other employees who is dealing with a risk. In category of small enterprises, in Poland the most respondents (15.33\%) identify risk by person responsible for risk management who is dealing with a risk. In Slovakia, $26.83 \%$ of respondents identify risks by responsible person in co-operation with other employees who is dealing with a risk. In small enterprises, in both countries the most respondents 
signed the possibility 4. If we compare situation in medium sized enterprises, in Poland the most respondents signed possibility 2 (6.00\%). In Slovakia, in three case $3.25 \%$ of respondents the risks identify by ways 2,3 and 4 .

The results of $p$-value in Poland (0.246) and Slovakia $(0 p=0.06)$ showed that there is not statistical dependence among ways of risk identification among observed sized categories of SMEs. It means that way by which respondents identify risks does not depend on size category, to which respondent belonged.

Tab. 5: The ways of risk identification in Poland and Slovakia according size category of respondents (\%)

\begin{tabular}{|l|l|l|l|l|l|l|l|l|}
\hline \multirow{2}{*}{ Responsible person } & \multicolumn{4}{|c|}{ Poland } & \multicolumn{4}{c|}{ Slovakia } \\
\cline { 2 - 9 } & \multicolumn{1}{|c|}{ ME } & \multicolumn{1}{|c|}{ SE } & \multicolumn{1}{|c|}{ MDE } & \multicolumn{1}{c|}{ Total } & \multicolumn{1}{c|}{ ME } & \multicolumn{1}{c|}{ SE } & MDE & \multicolumn{1}{c|}{ Total } \\
\hline 1. & 18.67 & 12.67 & 0.67 & $\mathbf{3 2 . 0 0}$ & 14.63 & 0.00 & 0.00 & $\mathbf{1 4 . 6 3}$ \\
\hline 2. & 18.67 & 15.33 & 6.00 & $\mathbf{4 0 . 0 0}$ & 14.63 & 4.88 & 3.25 & $\mathbf{2 2 . 7 6}$ \\
\hline 3. & 2.00 & 2.00 & 0.67 & $\mathbf{4 . 6 7}$ & 7.32 & 4.88 & 3.25 & $\mathbf{1 5 . 4 5}$ \\
\hline 4. & 9.33 & 6.00 & 4.00 & $\mathbf{1 9 . 3 3}$ & 26.83 & 10.57 & 3.25 & $\mathbf{4 0 . 6 5}$ \\
\hline 5. & 0.67 & 2.67 & 0.67 & $\mathbf{4 . 0 0}$ & 4.88 & 1.63 & 0.00 & $\mathbf{6 . 5 0}$ \\
\hline Total & 49.33 & 38.67 & 12.00 & $\mathbf{1 0 0 . 0 0}$ & 68.29 & 21.95 & 9.76 & $\mathbf{1 0 0 . 0 0}$ \\
\hline & \multicolumn{3}{|l}{ Pearson Chi-Sq.: 10.284; df=8. p=0.246 } & \multicolumn{2}{|c|}{ Pearson Chi-Sq.: 14.958; df=8. p=0.060 } \\
\hline
\end{tabular}

Source: Own research. ME - micro enterprises. SE - small enterprises. MDE medium enterprises.

Risk identification represents the process of finding, recognizing and description of risk. The approaches to risk identification and risk assessment in the company depend on the attitude of the executive person or person who is responsible of risk management (Haviernikova et al., 2016). For identification and assessment of risk various methods are used: appraisement, quality management, Balance Scorecard, interviews with staff and SWOT analysis. The respondents were asked, which kind of methods they use in risk identification and risks assessment. They marked their perception on the scale with values from 1 - always, 2 - very often, 3 - rarely, $4-$ never. The descriptive statistics present table 6 and respondents' perception in table 6 .

Tab. 6 The descriptive statistics of SMEs' perception of methods used for risk identification and assessment

\begin{tabular}{|l|c|c|c|c|}
\hline \multirow{2}{*}{ Method } & \multicolumn{2}{|c|}{ Poland } & \multicolumn{2}{c|}{ Slovakia } \\
\cline { 2 - 5 } & Mean & $\begin{array}{c}\text { Standard } \\
\text { deviation }\end{array}$ & Mean & Standard deviation \\
\hline Appraisement & 2.37 & 0.89 & 2.24 & 0.97 \\
\hline Quality Management & 2.46 & 0.91 & 2.44 & 1.13 \\
\hline Balance Scorecard & 3.20 & 0.88 & 3.11 & 1.19 \\
\hline SWOT Analysis & 3.18 & 0.88 & 2.75 & 1.21 \\
\hline Brainstorming & 2.86 & 0.97 & 2.77 & 1.28 \\
\hline
\end{tabular}

Source: Own research. 
The most frequently used methods for risk identification and assessment is the Balance Scorecard (Poland: $3.20 \pm 0.88$, Slovakia: $3.11 \pm 1.19$ ). We confirmed hypothesis H3.

The company identifies and reduces potential loss and liability by conduction prevention and risk reduction activities. In literature we can find several ways how the SMEs could do the risk prevention. In our research, we asked SMEs about five possibilities for risk prevention. As follows from Figure 1, the most respondents in Poland, as well as Slovakia apply different preventive measures as a way how to prevent the risk. For Polish entrepreneurs the common way of risk treatment is trying to limit the risk negative effects. Only $4.80 \%$ of Slovak respondents answered that their activity is not risky and $8.00 \%$ of Polish respondents answered, that they accept the risk as it is. We confirmed the hypothesis $\mathrm{H} 4$.

Figure 1. The ways of risk limiting in SMEs in Poland and Slovakia

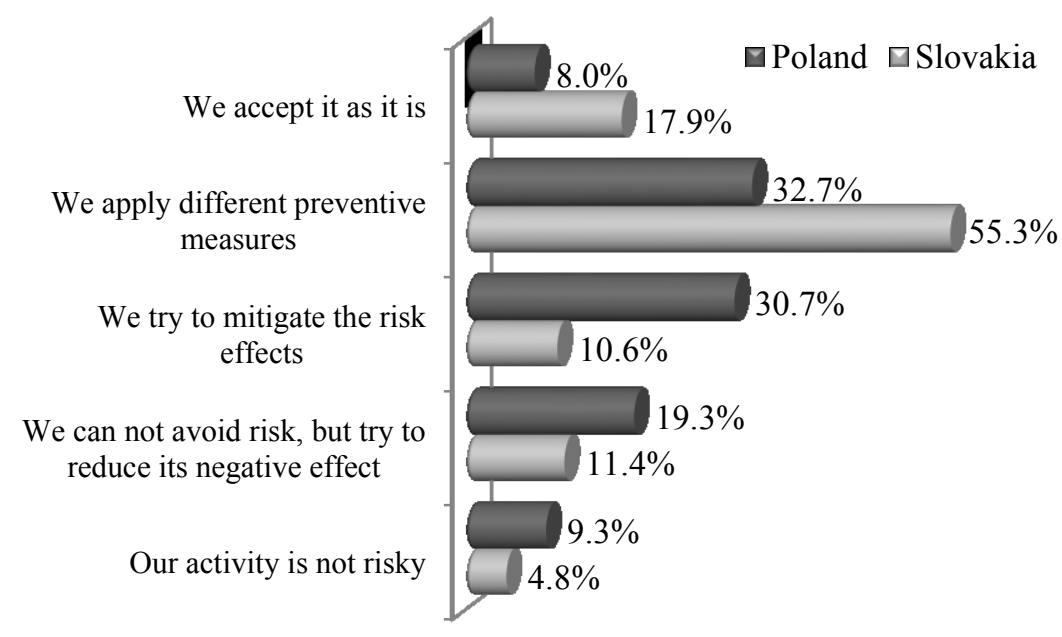

Source: Own research

\section{Conclusion}

Based on literature, the general understanding of risk management in SMEs is not univocal and the researches on implementations, methods and practice are limited (Verbano and Venturini, 2013). The possibility of implementing and sustaining risk management in SMEs is discussed in the literature especially regarding the creating of a holistic approach.

Many enterprises from the SME sector lack knowledge, resources, tools and management skills for proper risk management application (Brustbauer, 2016). The tools and developed solutions by large companies are usually not suitable to SMEs because of their high costs and complexity (Pereira et al., 2015), and, from this point of view, the SME managers consider those guidelines inapplicable because of the specific characteristics of their firms. It is commonly underlined, that resources to support risk management application are beyond capability and affordability of SMEs (de Araújo 
Lima, Chiara and Verbano, 2019). On the other hand, SMEs are more vulnerable to different kinds of risk than corporations, so they should be more engaged into risk management (Blanc Alquier and Lagasse Tignol, 2006). Despite this, SMEs are far from adopting a proactive risk management approach.

Risk management in practice means to cover the defined framework and steps supporting proactive culture, institutional structure, communication and incorporating risk management into enterprise management strategy. The crucial are suitable reactions to risks and application of these risks' solution to fulfil strategic objectives. The organization of risk management consists of several aspects that are necessary for risk management implementation in SME. This paper is focused on three main aspects of risk organization: responsibility of risk management, risk identification and risk treatment. This research showed the results of these aspects perception by Polish and Slovak SMEs.

In both countries, in over $80 \%$ of SMEs the risk management is realized by the owner. It is one of the main reasons of insufficient and inadequate risk management in these enterprises. As Jayathilake (2012) stated, risk management can be influenced by the experience, limited risk knowledge, beliefs and attitudes of the entrepreneurs, and from this point of view, can be not entirely professional. The research showed that, however, there is a multitude of risk models, which identifies all significant risks and analyses, prioritizes and manages those risks (Di Serio, et al., 2011), both Polish and Slovak SMEs use only limited number of those methods, and in limited scope.

The novelty of the paper is visible by exploring and comparing the selected aspects of enterprise risk management in two different countries. After the analysis, it was clearly verified that the research results vary, sometimes significantly, from country to country. This study contributes to the international resources of economic knowledge and could be the basis for preparing the recommendation for risk management improvements in SMEs.

This paper is not free of limitations. Main limitation of present research is the unrepresentative research sample, as well as managerial approach, which may distort the survey responses, the business owner treats emotionally with the company he/she created, and at the same time trying to put the firm in a the best possible light.

\section{References}

ABRHÁM, J., LŽIČǍ̌, P., 2018. Risk management in the sustainable development: Analysis of a selected key industry. Journal of Security and Sustainability Issues. 8(2), 171-180. doi:10.9770/jssi.2018.8.2(5)

BLANC ALQUIER, A. M., LAGASSE TIGNOL, M. H., 2006. Risk management in smallandmedium-sized enterprises. Production Planning \& Control, 17(3), 273-282. 
BORREGO. M., DOUGLAS. P., AMELINK. C.T., 2009. Quantitative. qualitative. and mixed research methods in engineering education. Journal of Engineering Education, 98(1), 5366.

BOUKALOVA, K., KOLAROVA, A., LOSTAK, M., 2016. Tracing shift in Czech rural development paradigm (Reflections of Local Action Groups in the media). Agricultural Economics-Zemedelska Ekonomika, 62(4), 149-159. doi: 10.17221/102/2015AGRICECON

BRUSTBAUER, J., 2016. Enterprise risk management in SMEs: Towards a structural model. International Small Business Journal, 34(1), 70-85.

CAHA, Z., 2017. Exploitation of External Financial Resources for Corporate Training Purposes in the Czech Republic. Littera Scripta, 10 (1), 10-21.

CAHA, Z., 2018. Dependence of Brand Loyalty on Customer Relationship Management. Littera Scripta, 11 (2), 7-19.

CAHA, Z., ŠULISTOVÁ, J., 2016. A Standardised Test as a Tool for the Reliable Verification of Acquired Knowledge. Littera Scripta, 9(1), 21-32.

DE ARAÚJO LIMA P.F., CHIARA VERBANO M.C., 2019. Risk management in SMEs: A systematic literature review and future directions, European Management Journal, In press.

HANULAKOVA, E., DANO, F., 2018. Circular Economy as a New Managerial Approach. $A D$ ALTA-Journal of Interdisciplinary Research, 8(1), 95-98.

HAVIERNIKOVÁ, K., OKRĘGLICKA, M., KLUČKA, J., 2016. Theoretical and Methodological Issues of Risk Management in Small and Medium-Sized Enterprises. Wien/Berlin: MercurVerlag. ISBN: 978-3-9504054-9-1

HELISEK, M., 2015. Perspectives of the Accession of the Czech Republic to the Euro Area in terms of the Price Level Convergence. Economics \& Sociology, 8(2), 28-35. doi: 10.14254/2071-789X.2015/8-2/3

HUDÁKOVÁ M., BUGÁNOVÁ K., MÍKA V.T., 2013. Metódy a techniky $v$ procese manažmentu rizika. Žilinská univerzita v Žiline. Žilina: EDIS - vydavatel'stvo ŽU. ISBN 978-80554-0642-8

HUDÁKOVÁ, M., DVORSKÝ, J., 2018. Assessing the risks and their sources in dependence on the rate of implementing the risk management process in the SMEs. Equilibrium. Quarterly Journal of Economics and Economic Policy, 13(3), 543-567. doi: 10.24136/eq.2018.027

HUDÁKOVÁ, M., MASÁR, M., 2018. Assessment of the Key Business Risks of the SMEs in Slovakia and Their Comparison with other EU Countries. Entrepreneurial Business and Economics Review, 6(4), 145-160. doi.org/10.15678/EBER.2018.060408

IVANOVÁ, E., MASÁROVÁ, J., 2018. Performance evaluation of the Visegrad Group countries. Economic Research-Ekonomska Istrazivanja, 31(1), 270-289. 
JAYATHILAKE, P. M. B., 2012. Risk management practices in small and medium enterprises: Evidence from Sri Lanka. International Journal of Multidisciplinary Research, 2(7), 226-2334.

JENICEK, V., 2016. Economic growth in the development economy. Agricultural Economics-Zemedelska Ekonomika, 62(2), 93-99. doi: 10.17221/234/2014-AGRICECON

JIRANKOVA, M., HNAT, P. 2012. Balance of payments adjustment mechanisms in the Euro area. Eastern Journal of European Studies, 3(1), 67-86.

JIROUDKOVA, A., ROVNA, L.A., 2015. EU Accession, Transition and Further Integration for the Countries of Central and Eastern Europe. Economics \& Sociology, 8(2), 11-14. doi: 10.14254/2071-789X.2015/8-2/1

KRAJNAKOVA, E., NAVIKAITE, A., NAVICKAS, V., 2015, Paradigm Shift of Small and Medium-Sized Enterprises Competitive Advantage to Management of Customer Satisfaction. Inzinerine Ekonomika-Engineering Economics, 26, 327-32. doi:10.5755/j01.ee.26.3.6608.

LIPKOVA, L., BRAGA, D., 2016. Measuring Commercialization Success of Innovations in the EU. Marketing and Management of Innovations, 4, 15-30.

LIPKOVA, L., GRESS, M., PONCAROVA, A., 2017. Tax systems in the Czech Republic and the Slovak Republic: Comparison with an emphasis on income tax. Economic Annals-XXI, 165, 47-51. doi:10.21003/ea.V165-10.

LIPKOVA, L., HOVORKOVA, K., 2018. Economic situation in Norway after the outbreak of the global financial and oil crises in the context of EU integration trends. Economic Annals-XXI, 169, 12-14.

MACHKOVA, H. and SATO, A., 2017. Analysis of Competitiveness of Belgian Sugar Industry. Listy Cukrovarnicke a Reparske, 133(12), 390-392.

MULLER, K., 2006. Innovation performance of new EU member countries - Situation in the Czech Republic. Politicka Ekonomie, 54(6), 778-801. doi: 10.18267/j.polek.583

MURA, L. and KLJUCNIKOV, A., 2018. Small Businesses in Rural Tourism and Agrotourism: Study from Slovakia. Economics \& Sociology, 11(3), 286-300.

NOCCO, B. W. and STULZ R. M., 2016. Enterprise Risk Management: Theory and Practice. Journal of Applied Corporate Finance. 18(4), 8-20.

PEREIRA, L., TENERA, A., BISPO, J., WEMANS, J., 2015. A Risk Diagnosing Methodology Web-Based Platform for Micro, Small and Medium Businesses: Remarks and Enhancements. In: Fred A., Dietz J., Liu K., Filipe J. (eds) Knowledge Discovery, Knowledge Engineering and Knowledge Management. IC3K 2013. Communications in Computer and Information Science, 454: 340-356. Springer, Berlin, Heidelberg.

SEJKORA, J., 2014. Poor Economics: A Radical Rethinking of the Way to Fight Global Poverty. Ekonomicky Casopis, 62(4), 431-435. 
SIRA, E., KRAVCAKOVA VOZAROVA, I., RADVANSKA, K., 2016. Using of risk management at small and medium-sized companies in the Slovak Republic/ Economic Annals-XXI, 156(1-2), 71-73

TAUŠER, J. and ČAJKA, R., 2014. Hedging techniques in commodity risk management. Agricultural Economics (Czech Republic), 60(4), 174-182.

VERBANO, C. and VENTURINI, K., 2013. Managing risks in SMEs: A literature review andresearch agenda. Journal of Technology Management\&Innovation, 8(3), 186-197.

WEISSOVÁ, I., SIEKELOVA, A., KRAMÁROVÁ, K., 2016. Modeling of company's default probability in relation to its credit risk. Global Journal of Business, Economics and Management: Current Issues, 6(2), 130-137. doi.org/10.18844/gjbem.v6i2.137.

ZADRAZILOVA, D., 2016. Current Trends in German Sugar Industry. Listy Cukrovarnicke a Reparske, 132(12), 390-393.

\section{Contact address of the author(s):}

Ing. Katarína Havierniková, Ph.D., Department of Economy and Economics. Faculty of Social and Economic Relations. Študentská 3, 91150 Trenčín. Slovakia. e-mail: katarina.haviernikova@tnuni.sk.

Małgorzata Okręglicka, Ph.D., Department of Economics, Investments and Real Estate, Faculty of Management, Czestochowa Unoversity of Technology, Poland. e-mail: m.okreglicka@wp.pl.

Ing. Marcel Kordoš, Ph.D., Department of Public Administration and Regional Economy. Faculty of Social and Economic Relations. Študentská 3, 91150 Trenčín. Slovakia. e-mail: marcel.kordos@tnuni.sk. 